\title{
IMA Commission on New Minerals, Nomenclature and Classification (CNMNC)
}

\author{
NEWSLETTER 30
}

\section{New minerals and nomenclature modifications approved in 2016}

\section{U. Hålenius ${ }^{1}$ (Chairman CNMNC), F. Hatert ${ }^{2}$ (Vice-Chairman CNMNC), M. Pasero ${ }^{3}$ (Vice-Chairman} CNMNC) AND S.J. Mills ${ }^{4}$ (SeCRETARY CNMNC)

1 Department of Mineralogy, Naturhistoriska Riksmuseet, Box 50007, SE-104 05 Stockholm, Sweden ulf.halenius@nrm.se

2 Laboratoire de Minéralogie, Université de Liège, B-4000 Liège, Belgium - fhatert@ulg.ac.be

3 Dipartimento di Scienze della Terra, Università di Pisa, Via Santa Maria 53, I-56126 Pisa, Italy marco.pasero@unipi.it

4 Geosciences, Museum Victoria, PO Box 666, Melbourne, Victoria 3001, Australia - smills@museum.vic.gov.au

The information given here is provided by the IMA Commission on New Minerals, Nomenclature and Classification for comparative purposes and as a service to mineralogists working on new species.

Each mineral is described in the following format:

Mineral name, if the authors agree on its release prior to the full description appearing in press Chemical formula

Type locality

Full authorship of proposal

E-mail address of corresponding author

Relationship to other minerals

Crystal system, Space group; Structure determined, yes or no

Unit-cell parameters

Strongest lines in the X-ray powder diffraction pattern

Type specimen repository and specimen number

Citation details for the mineral prior to publication of full description

Citation details concern the fact that this information will be published in the Mineralogical Magazine on a routine basis, as well as being added month by month to the Commission's web site.

It is still a requirement for the authors to publish a full description of the new mineral.

NO OTHER INFORMATION WILL BE RELEASED BY THE COMMISSION 


\section{NEW MINERAL PROPOSALS APPROVED IN FEBRUARY 2016}

\section{IMA No. 2015-089}

Verbierite

$\mathrm{BeCr}_{2}^{3+} \mathrm{TiO}_{6}$

Savoleyres, north of Verbier, Wallis, Switzerland (4606'11.16’N, 7¹3'25.99'”, $1577 \mathrm{~m}$ asl)

Nicolas Meisser*, Remo Widmer, Thomas Armbruster, Eric May, François Bussy, Alexey Ulianov and Pierre-Maurice Michellod

*E-mail: nicolas.meisser@unil.ch

The $\mathrm{Cr}$ analogue of byrudite

Orthorhombic: Pnma; structure determined $a=9.933(2), b=8.458(2), c=4.511(1) \AA$ $4.10(20), 3.70(60), 2.54(60), 2.25(30), 1.670$ (100), 1.661(60), 1.428(30), 1.351(30)

Type material is deposited in the collections of the Musée Cantonal de Géologie, Lausanne, Switzerland, registration numbers MGL 93100 and MGL 93101

How to cite: Meisser, N., Widmer, R., Armbruster, T., May, E., Bussy, F., Ulianov, A. and Michellod, P.M. (2016) Verbierite, IMA 2015-089. CNMNC Newsletter No. 30, April 2016, page 408; Mineralogical Magazine, 80, 407-413.

\section{IMA No. 2015-100}

Kannanite

$\mathrm{Ca}_{4} \mathrm{Al}_{4}(\mathrm{MgAl})\left(\mathrm{VO}_{4}\right)\left(\mathrm{SiO}_{4}\right)_{2}\left(\mathrm{Si}_{3} \mathrm{O}_{10}\right)(\mathrm{OH})_{6}$

Kannan Mountain, Ozu City, Ehime Prefecture,

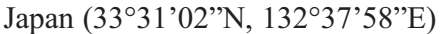

Daisuke Nishio-Hamane* and Tetsuo Minakawa

*E-mail: hamane@issp.u-tokyo.ac.jp

The $\mathrm{Ca}$ analogue of ardennite-(V)

Orthorhombic: Pnmm

$a=8.881(1), b=5.992(1), c=18.879(2) \AA$

4.720(34), 3.234(37), 3.001(100), 2.809(35),

2.715(66), 2.657(67), 2.531(47), 2.306(37)

Type material is deposited in the mineralogical collections of the National Museum of Nature and Science, Tsukuba, Japan, specimen number NSM M-44527

How to cite: Nishio-Hamane, D. and Minakawa, T. (2016) Kannanite, IMA 2015-100. CNMNC Newsletter No. 30, April 2016, page 408; Mineralogical Magazine, 80, 407-413.
IMA No. 2015-102

Metathénardite

$\mathrm{Na}_{2} \mathrm{SO}_{4}$

Glavnaya Tenoritovaya (Major Tenorite) fumarole, Second scoria cone of the Northern Breakthrough of the Great Tolbachik Fissure Eruption, Tolbachik volcano, Kamchatka Peninsula, Far-Eastern Region, Russia (55 $41^{\prime} \mathrm{N}, 160^{\circ} 14^{\prime} \mathrm{E}, 1200 \mathrm{~m}$ asl)

Igor V. Pekov*, Vladislav V. Gurzhiy, Natalia V. Zubkova, Atali A. Agakhanov, Dmitry I. Belakovskiy, Marina F. Vigasina and Evgeny G. Sidorov

*E-mail: igorpekov@mail.ru

A dimorph of thénardite

Hexagonal: $P 6_{3} / m m c$; structure determined $a=5.3467(9), c=7.088(2) \AA$

$4.667(27), \quad 3.904(89), \quad 3.565(33), \quad 2.824(94)$, 2.686(100), 2.325(12), 2.203(10), 1.939(35)

Type material is deposited in the collections of the Fersman Mineralogical Museum of the Russian Academy of Sciences, Moscow, Russia, registration number 4771/1

How to cite: Pekov, I.V., Gurzhiy, V.V., Zubkova, N. V., Agakhanov, A.A., Belakovskiy, D.I., Vigasina, M.F. and Sidorov, E.G. (2016) Metathénardite, IMA 2015-102. CNMNC Newsletter No. 30, April 2016, page 408; Mineralogical Magazine, 80, 407-413.

IMA No. 2015-103

Hansblockite

$(\mathrm{Cu}, \mathrm{Hg})(\mathrm{Bi}, \mathrm{Pb}) \mathrm{Se}_{2}$

El Dragón mine, Quijarro province, Potosí, Bolivia (1949'23.90”'S, 65'55'00.60”'W, $4160 \mathrm{~m}$ asl)

Hans-Jürgen Förster*, Luca Bindi, Christopher J. Stanley and Günter Grundmann

*E-mail: forhj@gfz-potsdam.de

A dimorph of grundmannite

Monoclinic: $P 2_{1} / c$; structure determined

$a=6.853(1), b=7.635(2), c=7.264(1) \AA, \beta=$ $97.68(1)^{\circ}$

$3.97(90), \quad 3.100(40), \quad 2.986(100), \quad 2.808(50)$, 2.620(60), 2.534(25), 2.385(30), 2.290(35)

Type material is deposited in the mineralogical collections of the Natural History Museum, London, catalogue number BM 2015,136

How to cite: Förster, H.-J., Bindi, L., Stanley, C.J. and Grundmann, G. (2016) Hansblockite, IMA 2015-103. CNMNC Newsletter No. 30, April 2016, page 408; Mineralogical Magazine, 80, 407-413. 
IMA No. 2015-104

Magnesiovesuvianite

$\mathrm{Ca}_{19} \mathrm{Mg}\left(\mathrm{Al}_{10} \mathrm{Mg}_{2}\right) \mathrm{Si}_{18} \mathrm{O}_{68}(\mathrm{OH})_{10}$

Tuydo combe, near Lojane, Macedonia

Taras L. Panikorovskii*, Vladimir V. Shilovskikh,

Evgenia Y. Avdontseva, Andrey A. Zolotarev,

Vladimir Y. Karpenko, Anton S. Mazur, Victor

N. Yakovenchuk, Sergey V. Krivovichev and Igor

V. Pekov

*E-mail: taras.panikorovsky@spbu.ru

Vesuvianite group

Tetragonal: $P 4 / n$; structure determined

$a=15.5363(2), c=11.7965(3) \AA$

$10.96(23), 3.464(22), 3.038(33), 2.740(100)$,

2.583(21), 2.365(94), 2.192(19), 1.616(25)

Type material is deposited in the collections of the Fersman Mineralogical Museum of the Russian Academy of Sciences, Moscow, Russia, catalogue no. 59783

How to cite: Panikorovskii, T.L., Shilovskikh, V. V., Avdontseva, E.Y., Zolotarev, A.A., Karpenko, V.Y., Mazur, A.S., Yakovenchuk, V.N., Krivovichev, S.V. and Pekov, I.V. (2016) Magnesiovesuvianite, IMA 2015-104. CNMNC Newsletter No. 30, April 2016, page 409; Mineralogical Magazine, 80, 407-413.

IMA No. 2015-105

Russoite

$\left(\mathrm{NH}_{4}\right) \mathrm{ClAs}_{2} \mathrm{O}_{3}\left(\mathrm{H}_{2} \mathrm{O}\right)_{0.5}$

"Bocca Grande" fumarole, Solfatara, Pozzuoli (NA), Italy (4049'41'”N, 148'30”E)

Italo Campostrini*, Francesco Demartin and Marco Scavini

*E-mail: italo.campostrini@unimi.it

Known synthetic analogue

Hexagonal: $P 622$

$a=5.259(2), c=12.590(5) \AA$

12.627(19), 6.324(100), 4.547(75), 4.218(47),

3.094(45), 2.627(47), 2.428(31), 1.820(28)

Type material is deposited in the Reference

Collection of the DCSSI, Università di Milano,

Via C. Golgi 19, I-20133 Milano, Italy, sample no. 2015-01

How to cite: Campostrini, I., Demartin, F. and Scavini, M. (2016) Russoite, IMA 2015105. CNMNC Newsletter No. 30, April 2016, page 409; Mineralogical Magazine, 80, 407-413.
IMA No. 2015-106

Dioskouriite

$\mathrm{CaCu}_{4} \mathrm{Cl}_{6}(\mathrm{OH})_{4} \cdot 4 \mathrm{H}_{2} \mathrm{O}$

In two active fumaroles, Glavnaya Tenoritovaya (Major Tenorite) (holotype) and Arsenatnaya (cotype), both at the Second scoria cone of the Northern Breakthrough of the Great Tolbachik Fissure Eruption, Tolbachik volcano, Kamchatka Peninsula, Far-Eastern Region, Russia (55 $41^{\prime} \mathrm{N}$, $160^{\circ} 14^{\prime} \mathrm{E}, 1200 \mathrm{~m}$ asl)

Igor V. Pekov*, Natalia V. Zubkova, Andrey A. Zolotarev, Vasiliy O. Yapaskurt, Sergey V. Krivovichev, Dmitry I. Belakovskiy, Inna S. Lykova, Marina F. Vigasina, Anatoly V. Kasatkin, Evgeny G. Sidorov and Dmitry Y. Pushcharovsky *E-mail: igorpekov@mail.ru

New structure type

$2 M$ polytype - Monoclinic: $P 2_{1} / c$; structure determined

$a=7.2792(8), b=10.3000(7), c=20.758(2) \AA, \beta$ $=100.24(1)^{\circ}$

$2 O$ polytype - Orthorhombic: $P 2_{1} 2_{1} 2_{1}$; structure determined

$a=7.3193(7), b=10.371(1), c=20.560(3) \AA$

$2 M$ polytype $-10.29(100), 5.960(22), 5.754(7)$, $5.492(11), \quad 5.170(16), \quad 5.035(13), \quad 2.737(28)$, $2.417(8)$

$2 O$ polytype $-10.34(100), 5.940(15), 5.754(9)$, 5.177(13), 5.033(10), 2.735(21), 2.524(6), 2.318(8) Type material is deposited in the collections of the Fersman Mineralogical Museum of the Russian Academy of Sciences, Moscow, Russia, registration number $4803 / 1$

How to cite: Pekov, I.V., Zubkova, N.V., Zolotarev, A.A., Yapaskurt, V.O., Krivovichev, S.V., Belakovskiy, D.I., Lykova, I.S., Vigasina, M.F., Kasatkin, A.V., Sidorov, E.G. and Pushcharovsky, D.Y. (2016) Dioskouriite, IMA 2015-106. CNMNC Newsletter No. 30, April 2016, page 409; Mineralogical Magazine, 80, 407-413.

\section{NEW MINERAL PROPOSALS APPROVED IN MARCH 2016}

IMA No. 2015-107

Zincobotryogen

$\mathrm{ZnFe}^{3+}\left(\mathrm{SO}_{4}\right)_{2}(\mathrm{OH}) \cdot 7 \mathrm{H}_{2} \mathrm{O}$

Xietieshan lead-zinc deposit, Qinghai Province, China 
Zhuming Yang*, Gerald Giester, Qian Mao,

Yuguang Ma, Di Zhang and $\mathrm{He} \mathrm{Li}$

*E-mail: yangzhm@mail.igcas.ac.cn

The $\mathrm{Zn}$ analogue of botryogen

Monoclinic: $P 2_{1} / n$; structure determined

$a=10.504(2), b=17.801(4), c=7.126(1) \AA, \beta=$ $100.08(3)^{\circ}$

8.92(100), 6.32(77), 5.56(23), 5.14(45), 4.08

(22), 3.76(20), 3.21(31), 3.03(34)

Type material is deposited in the mineralogical collections of the Museum of the Institute of Geology and Geophysics, Chinese Academy of Sciences, P.O.Box 9825, Beijing 100029, China, registration number KDX067

How to cite: Yang, Z., Giester, G., Mao, Q., Ma, Y., Zhang, D. and Li, H. (2016) Zincobotryogen, IMA 2015-107. CNMNC Newsletter No. 30, April 2016, page 409; Mineralogical Magazine, 80, 407-413.

\section{IMA No. 2015-108}

Philoxenite

$(\mathrm{K}, \mathrm{Na}, \mathrm{Pb})_{4}(\mathrm{Na}, \mathrm{Ca})_{2}(\mathrm{Mg}, \mathrm{Cu})_{3}\left(\mathrm{Fe}_{0.5}^{3+} \mathrm{Al}_{0.5}\right)\left(\mathrm{SO}_{4}\right)_{8}$ Yadovitaya (Poisonous) fumarole, Second scoria cone of the Northern Breakthrough of the Great Tolbachik Fissure Eruption, Tolbachik volcano, Kamchatka peninsula, Far-Eastern Region, Russia $\left(55^{\circ} 41^{\prime} \mathrm{N}, 160^{\circ} 14^{\prime} \mathrm{E}, 1200 \mathrm{~m}\right.$ asl)

Igor V. Pekov*, Natalia V. Zubkova, Atali A. Agakhanov, Dmitry I. Belakovskiy, Marina F. Vigasina, Sergey N. Britvin, Anna G. Turchkova, Evgeny G. Sidorov and Dmitry Y. Pushcharovsky

*E-mail: igorpekov@mail.ru

New structure type

Triclinic: $P \overline{1}$; structure determined $a=8.8410(3), b=8.9971(3), c=16.1861(5) \AA$, $\alpha=91.927(3), \beta=94.516(3), \gamma=90.118(3)^{\circ}$ $5.70(18), \quad 4.030(24), \quad 3.146(100), \quad 3.136(72)$, 2.965(36), 2.912(35), 2.834(36), 2.784(42)

Type material is deposited in the collections of the Fersman Mineralogical Museum of the Russian Academy of Sciences, Moscow, Russia, registration number 4809/1

How to cite: Pekov, I.V., Zubkova, N.V., Agakhanov, A.A., Belakovskiy, D.I., Vigasina, M.F., Britvin, S.N., Turchkova, A.G., Sidorov, E.G. and Pushcharovsky, D.Y. (2016) Philoxenite, IMA 2015-108. CNMNC Newsletter No. 30, April 2016, page 410; Mineralogical Magazine, 80, 407-413.
IMA No. 2015-109

Marcobaldiite

$\mathrm{Pb}_{12}\left(\mathrm{Sb}_{3} \mathrm{As}_{2} \mathrm{Bi}\right)_{\Sigma 6} \mathrm{~S}_{21}$

Stanzone tunnel, Pollone mine, Pietrasanta,

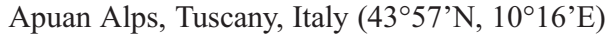

Cristian Biagioni*, Marco Pasero, Yves Moëlo,

Federica Zaccarini, Werner H. Paar and Stefano Merlino

*E-mail: biagioni@dst.unipi.it

Jordanite homologous series

Triclinic: $P \overline{1}$; structure determined

$a=8.9248(9), b=29.414(3), c=8.5301(8) \AA, \alpha=$ 98.336(5), $\beta=118.175(5), \gamma=90.856(5)^{\circ}$

$3.568(\mathrm{~ms}), \quad 3.202(\mathrm{~ms}), \quad 3.016(\mathrm{~ms}), \quad 2.885(\mathrm{~ms})$, 2.233(vs), 2.125(s), 1.848(s), 1.775(vs)

Type material is deposited in the mineralogical collections of the Museo di Storia Naturale, Università di Pisa, Via Roma 79, Calci (Pisa), Italy, catalogue number 19709

How to cite: Biagioni, C., Pasero, M., Moëlo, Y., Zaccarini, F., Paar, W.H. and Merlino, S. (2016) Marcobaldiite, IMA 2015-109. CNMNC Newsletter No. 30, April 2016, page 410; Mineralogical Magazine, 80, 407-413.

\section{IMA No. 2015-111}

Petř́íčekite

$\mathrm{CuSe}_{2}$

Předbořice deposit, Central Bohemia Region, Czech Republic (4932.16’ N, 14 $\left.{ }^{\circ} 13.55^{\prime} \mathrm{E}\right)$

Luca Bindi*, Hans-Jürgen Förster, Günter Grundmann, Frank N. Keutsch and Christopher J. Stanley

*E-mail: luca.bindi@unifi.it

A dimorph of krut'aite

Orthorhombic: Pnnm; structure determined $a=4.918(2), b=6.001(2), c=3.670(1) \AA$ $3.135(20), 2.938(70), 2.639(100), 2.563(85)$, 1.935(70), 1.834(30), 1.760(25), 1.492(25)

Type material is deposited in the collections of the Harvard Mineralogical \& Geological Museum, Cambridge, MA 02138, USA, reference number MGMH\#2016.01

How to cite: Bindi, L., Förster, H.-J., Grundmann, G., Keutsch, F.N. and Stanley, C.J. (2016) Petříčekite, IMA 2015-111. CNMNC Newsletter No. 30, April 2016, page 410; Mineralogical Magazine, 80, 407-413. 
April 2016, page 411; Mineralogical Magazine, 80, 411-413.

IMA No. 2015-112

Hodgesmithite

$(\mathrm{Cu}, \mathrm{Zn})_{6} \mathrm{Zn}\left(\mathrm{SO}_{4}\right)_{2}(\mathrm{OH})_{10} \cdot 3 \mathrm{H}_{2} \mathrm{O}$

Block 14 Opencut, Broken Hill, New South

Wales, Australia

Peter Elliott

*E-mail: peter.elliott@adelaide.edu.au

Closely related to schulenbergite

Trigonal: $P 3$; structure determined

$a=8.190(1), c=7.099(1) \AA$

7.098(100), 5.020(5), 3.550(19), 3.173(19),

2.681(16), 2.509(19), 2.138(6), 1.772(4)

Type material is deposited in the mineralogical collections of the South Australian Museum, Adelaide, Australia, registration number G34298 How to cite: Elliott, P. (2016) Hodgesmithite, IMA 2015-112. CNMNC Newsletter No. 30, April 2016, page 411; Mineralogical Magazine, 80, 407-413.

\section{IMA No. 2015-113}

Borisenkoite

$\mathrm{Cu}_{3}\left[(\mathrm{~V}, \mathrm{As}) \mathrm{O}_{4}\right]_{2}$

Yadovitaya (Poisonous) fumarole, Second scoria cone of the Northern Breakthrough of the Great Tolbachik Fissure Eruption, Tolbachik volcano, Kamchatka peninsula, Far-Eastern Region, Russia $\left(55^{\circ} 41^{\prime} \mathrm{N}, 160^{\circ} 14^{\prime} \mathrm{E}, 1200 \mathrm{~m}\right.$ asl)

Igor V. Pekov*, Natalia V. Zubkova, Vasiliy O. Yapaskurt, Yury S. Polekhovsky, Marina F. Vigasina, Sergey N. Britvin, Anna G. Turchkova, Evgeny G. Sidorov and Dmitry Y. Pushcharovsky

*E-mail: igorpekov@mail.ru

The $\mathrm{V}$ analogue of lammerite- $\beta$

Monoclinic: $P 2_{1} / c$; structure determined $a=6.3797(6), b=8.6052(1), c=11.348(1) \AA, \beta=$ $91.985(8)^{\circ}$

4.309(48), 3.424(40), 2.994(48), 2.917(50), 2.868(72), 2.830(100), 2.782(54), 2.568(38)

Type material is deposited in the collections of the Fersman Mineralogical Museum of the Russian Academy of Sciences, Moscow, Russia, registration number 4824/1

How to cite: Pekov, I.V., Zubkova, N.V., Yapaskurt, V.O., Polekhovsky, Y.S., Vigasina, M.F., Britvin, S.N., Turchkova, A.G., Sidorov, E. G. and Pushcharovsky, D.Y. (2016) Borisenkoite, IMA 2015-113. CNMNC Newsletter No. 30,

\section{IMA No. 2015-114}

Kegginite

$\mathrm{Pb}_{3} \mathrm{Ca}_{3}\left[\mathrm{AsV}_{12} \mathrm{O}_{40}(\mathrm{VO})\right] \cdot 20 \mathrm{H}_{2} \mathrm{O}$

Packrat mine, near Gateway, Mesa Co., Colorado, USA (38³8'51.28'N, 10902'49.77'W)

Anthony R. Kampf*, Barbara P. Nash, Joe Marty and John M. Hughes

*E-mail: akampf@nhm.org

New structure type

Trigonal: $P \overline{3}$; structure determined $a=14.936(5), c=15.846(3) \AA$

15.846(89), 12.935(100), 10.020(43), 4.161(8), 3.499(9), 3.078(9), 2.968(10), 2.917(18)

Cotype material is deposited in the mineralogical collections of the Natural History Museum of Los Angeles County, Los Angeles, California, USA, catalogue numbers 65636, 65637 and 65638

How to cite: Kampf, A.R., Nash, B.P., Marty, J. and Hughes, J.M. (2016) Kegginite, IMA 2015-114. CNMNC Newsletter No. 30, April 2016, page 411; Mineralogical Magazine, 80, 407-413.

\section{IMA No. 2015-115}

Middlebackite

$\mathrm{Cu}_{2} \mathrm{C}_{2} \mathrm{O}_{4}(\mathrm{OH})_{2}$

Iron Monarch quarry, Iron Knob, Middleback Range, Eyre Peninsula, South Australia, Australia (3244'41'S, 1378'22'"E)

Peter Elliott

*E-mail: peter.elliott@adelaide.edu.au

New structure type

Monoclinic: $P 2_{1} / c$; structure determined $a=7.268(1), b=5.749(1), c=5.684(1) \AA$, $\beta=104.51(2)^{\circ}$

$7.070(16), \quad 3.739(100), \quad 2.905(7), \quad 2.860(18)$, 2.760(6), 2.481(12), 2.373(8), 2.350(9)

Type material is deposited in the mineralogical collections of the South Australian Museum, Adelaide, Australia, registration number G34300 How to cite: Elliott, P. (2016) Middlebackite, IMA 2015-115. CNMNC Newsletter No. 30, April 2016, page 411; Mineralogical Magazine, 80, 407-413. 
IMA No. 2015-116

Spryite

$\mathrm{Ag}_{8}\left(\mathrm{As}_{0.5}^{3+} \mathrm{As}_{0.5}^{5+}\right) \mathrm{S}_{6}$

Uchucchacua polymetallic deposit, Oyon district, Catajambo, Lima Department, Peru (10³7'23”'S, 76² 41 '18'W)

Luca Bindi*, Frank N. Keutsch and Federica

Zaccarini

*E-mail: luca.bindi@unifi.it

The As analogue of argyrodite

Orthorhombic: Pna2 1 ; structure determined $a=14.984(4), b=7.474(1), c=10.571(2) \AA$

$3.192(29), 3.056(31), 3.051(100), 2.781(29)$,

2.687(68), 2.604(29), 2.461(33), 1.870(37)

Type material is deposited in the mineralogical collections of the Museo di Storia Naturale, Università di Firenze, Via La Pira 4, Florence, Italy, catalogue number 3213/I

How to cite: Bindi, L., Keutsch, F.N. and Zaccarini, F. (2016) Spryite, IMA 2015-116. CNMNC Newsletter No. 30, April 2016, page 412; Mineralogical Magazine, 80, 407-413.

IMA No. 2015-117

Zincoberaunite

$\mathrm{ZnFe}_{5}^{3+}\left(\mathrm{PO}_{4}\right)_{4}(\mathrm{OH})_{5} \cdot 6 \mathrm{H}_{2} \mathrm{O}$

Hagendorf South granitic pegmatite, Hagendorf, Waidhaus, Upper Palatinate, Bavaria, Germany (49³9' '’’N, 12²7'35’'E)

Nikita V. Chukanov*, Igor V. Pekov, Dmitry I. Belakovskiy, Sergey N. Britvin and Bernhard Dünkel

*E-mail: nikchukanov@yandex.ru

The $\mathrm{Zn}$ analogue of beraunite

Monoclinic: $C 2 / c$; structure determined

$a=20.931(9), b=5.159(3), c=19.225(6) \AA$, $\beta=93.34(9)^{\circ}$

10.37(100), 9.58(32), 7.24(26), 4.817(22), 3.483

(14), 3.431(14), 3.194(15), 3.079(33)

Type material is deposited in the collections of the

Fersman Mineralogical Museum of Russian

Academy of Sciences, Moscow, Russia, registration number $4828 / 1$

How to cite: Chukanov, N.V., Pekov, I.V., Belakovskiy, D.I., Britvin, S.N. and Dünkel, B. (2016) Zincoberaunite, IMA 2015-117. CNMNC Newsletter No. 30, April 2016, page 412; Mineralogical Magazine, 80, 407-413.
IMA No. 2015-118

Eleomelanite

$\left(\mathrm{K}_{2} \mathrm{~Pb}\right) \mathrm{Cu}_{4} \mathrm{O}_{2}\left(\mathrm{SO}_{4}\right)_{4}$

Arsenatnaya fumarole, Second scoria cone of the Northern Breakthrough of the Great Tolbachik Fissure Eruption, Tolbachik volcano, Kamchatka

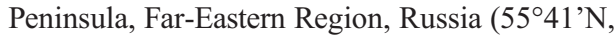
$160^{\circ} 14^{\prime} \mathrm{E}, 1200 \mathrm{~m}$ asl)

Igor V. Pekov*, Natalia V. Zubkova, Atali A. Agakhanov, Nikita V. Chukanov, Dmitry I. Belakovskiy, Evgeny G. Sidorov, Sergey N. Britvin and Dmitry Y. Pushcharovsky

*E-mail: igorpekov@mail.ru

Related to wulffite and parawulffite

Monoclinic: $P 2_{1} / n$; structure determined

$a=9.3986(3), b=4.8911(1), c=18.2293(5) \AA$,

$\beta=104.409(3)^{\circ}$

9.07(63), 7.38(44), 3.699(78), 3.658(100), 3.173

(40), 2.915(35), 2.683(36), 2.576(51)

Type material is deposited in the collections of the Fersman Mineralogical Museum of the Russian Academy of Sciences, Moscow, Russia, registration number 4827/1

How to cite: Pekov, I.V., Zubkova, N.V., Agakhanov, A.A., Chukanov, N.V., Belakovskiy, D.I., Sidorov, E.G., Britvin, S.N. and Pushcharovsky, D.Y. (2016) Eleomelanite, IMA 2015-118. CNMNC Newsletter No. 30, April 2016, page 412; Mineralogical Magazine, 80, 407-413.

IMA No. 2015-119

Kalgoorlieite

$\mathrm{As}_{2} \mathrm{Te}_{3}$

Golden Mile gold mining district, Kalgoorlie, Western Australia, Australia

Kirsten Rempel* and Christopher J. Stanley

*E-mail: kirsten.rempel@curtin.edu.au

Known synthetic analogue

Monoclinic: $C 2 / m$

$a=14.3573(9), b=4.0199(2), c=9.8990(7) \AA$, $\beta=95.107(5)^{\circ}$

$3.025(100), \quad 3.009(99), 2.330(46), 2.269(40)$,

2.001(59), 1.979(52), 1.674(35), 1.634(28)

Type material is deposited in the collections of the Western Australian Museum, Perth Cultural Centre, James Street, Perth, Western Australia 6000, Australia, catalogue number WAM M2.2015 
How to cite: Rempel, K. and Stanley, C.J. (2016) Kalgoorlieite, IMA 2015-119. CNMNC Newsletter No. 30, April 2016, page 412; Mineralogical Magazine, 80, 407-413.

\section{NOMENCLATURE PROPOSALS APPROVED IN MARCH 2016}

\section{Nomenclature of the perovskite supergroup}

A new nomenclature scheme for the perovskite supergroup has been approved by the CNMNC. This hierarchical scheme can be applied to naturally-occurring oxides, fluorides, hydroxides, chlorides, arsenides and silicates. Application of this hierarchical scheme to naturally-occurring minerals results in the recognition of a perovskite supergroup which is divided into stoichiometric and non-stoichiometric perovskite groups, with both groups further divided into single $\mathrm{ABX}_{3}$ or double $\mathrm{A}_{2} \mathrm{BB}^{\prime} \mathrm{X}_{6}$ perovskites.

\section{6-B: Partzite (discredited)}

Proposal 16-B is accepted, and partzite is discredited. Reinvestigation of the type material shows that it is constituted by a mixture of several phases, which include a member of the plumboroméite group and a chrysocolla-like amorphous phase.

16-C: Parabariomicrolite (discredited)

Proposal 16-C is accepted, and parabariomicrolite is discredited. It corresponds to the polytype hydrokenomicrolite- $3 R$. 